\title{
FUNCTIONAL RECONVERSION OF CENTRAL SQUARES AS SHOWN IN POSTCARDS: RUPEA / KÖHALOM / REPS TOWN, ROMANIA
}

\author{
Zoltan MAROȘI \\ Babeş-Bolyai University, Cluj-Napoca, Faculty of Geography, Centre for Research on Settlements and Urbanism, ROMANIA \\ zoltan_marosi@yahoo.de \\ DOI: http://doi.org/10.23740/TID120181
}

\section{ABSTRACT}

Deltiology, the study and collection of postcards, is a relatively new term, introduced in the dictionaries only in the middle of the 20th century. However, studying and collecting postcards is a much older concern and it is directly linked to the history of photography from the first half of the 19th century. The introduction of postcards in Romania and, especially in Transylvania, was achieved mainly through Western influences, proved by the greater number of available relevant postcards with reference to Transylvania than to the other historical extra-Carpathian provinces. Based on a modest but very relevant collection of postcards, this research aims to enrich the knowledge about the little-known town Rupea and especially to encourage the urban history research using unconventional sources of information, methodologies and methods. In this case the collection of postcards will be analysed, sorted and ordered chronologically after the most accurate dating possible, so as to display the distinct stages in the evolution of Rupea town's central square from an animated market in the past to a quiet and picturesque park at present. Thus, this evolution also implies a functional reconversion of the town's central square whose phases are immortalized by illustrations starting with 1851 until 2018. During this time, the town of Rupea was part of three different national administrations, until 1867 it was part of the Habsburg Empire, between 1867-1918 it was under the administration of the Hungarian Kingdom which was part of the Austro-Hungarian Empire and since 1918, or after the Treaty of Trianon, it became part of Romania (which was a monarchy, a socialist republic, and since 1991 a democratic republic). Therefore, the analysed period has not only a strong historical significance for the Transylvanian settlements but also includes the entire evolution and formation of the current cultural landscapes. In order to achieve the purpose of this article, the illustrated postcards will be redrawn, identified, described and interpreted in accordance with the territorial planning procedures, contributing to the consolidation of the history and local identity, as part of a long-term and sustainable development.

Keywords: postcards, urban landscape, evolution, reconversion, central squares, parks, Rupea, Kőhalom, Reps

\section{INTRODUCTION}

In an era of globalization in which most decisions and actions are profit-oriented, as Gallion \& Eisner noticed four decades ago, "the city became a vast commercial enterprise" (1980, p. 395) and the main purpose of urban planners was diverted to the technical and juridical aspects of the urban management to the detriment of aesthetics and urban design. In the long term, this imbalance is the reason why many cities are gradually losing the elements that confers them their identity, sedimented over several centuries of organic development driven mainly by natural factors. Places inhabited and transformed for centuries face the danger of becoming complex and meaningless structures, created in a context of historical and cultural vacuum and the population of these places, without attachment and confronted with apathy, has become immune to "the ugliness around them and incompetent to make judgements on urban aesthetics" (Gallion \& Eisner, 1980, p. 395, pp. 397-399).

Considering that around one-third of a city's surface is public domain, over which the public administration has full jurisdiction, and the fact that most of the surface and the buildings are 
privately owned, the concern for urban aesthetics also fall under the decisions taken by the urban population, especially owners and other private associations. However, in the last half century, major changes in the demographic structure of the population of Transylvanian settlements have greatly contributed to the decline of the "new" settlers' feeling of belonging to the places. After the end of the Second World War there have been numerous events that primarily affected the minorities living in Transylvania - a multicultural region by excellence in which Romanians, Hungarians (Szeklers) Saxons, Roma and others coexisted for centuries. According to Poledna through the implementation of the Land Reform Regulation from 1945, the German population (mainly Saxons) with Romanian citizenship and who were part of the German army or took part in the Nazi propaganda have been subjected to expropriations, so roughly 154,500 households were confiscated and transferred to the state property in Transylvania (2001, p. 99). The properties were then given to the peasants who had merits in the war against the European Axis (to which Romania was a member until the night of 23 August 1944, when Romania switched sides). Such major upheavals have irremediably affected the demographic structure of the Transylvanian settlements (Wagner, 2000, p. 85). The relevance of these sensitive issues for our research is that the landscape and the patrimony buildings of the former Saxon villages, such as fortified churches, remained abandoned because they were not used by the "new" majority settlers who had other religions and also because their lack of a feeling that they belong to the rural Saxon area (Ilovan \& Maroși, 2015, p. 65).

After the Second World War, Northern Transylvania was recovered by Romania, but at the same time, the after war Soviet occupation supported and encouraged the rise to power of the Communist Party, followed by the forced abdication of King Michael I in 1947. From that moment Romania has become a people's republic with a single-party (Wagner, 2000, p. 86). The collectivization of the agricultural sector followed in stages and then the nationalization of banks, mines, industries and transportations has increased the level of dependency of the society on social welfare benefits, controlled by the state and therefore has been developed a dependency culture which led to the annihilation of the entrepreneurial spirit of the population. Mass industrialization and urbanization implied the relocation of a large population from rural areas to the cities and thus the conservative rural mentality was artificially incorporated into the reshaped cities. According to the Demographic Yearbook of Romania 2015 the domestic migrations from rural to urban areas in 1970 has reached $37.5 \%$ of the total domestic migrations while in 2014 it was only $21.1 \%$. More relevant to the present are the domestic migrations from urban to rural areas which have reached values of $29.8 \%$ of the total domestic migrations in 2014 while the same indicator was only 10.9\% in 1970 (Drăgoescu, 2015, p. 17). In 1960 the urban population of Romania was 5,912,011 people (32.1\% of total) growing up to $7,464,811$ people $(36.9 \%)$ in 1970 and $12,311,803$ people $(53.2 \%)$ in 1989 , the year of the revolution, after which the values have fallen to 10,584,266 (53.7\%) in 2016 (Andrei, 2018, pp. 52-55). The poorer economy of post-socialist Romania and, above all, the problems of food shortages has led to the increased migrations in rural areas where foodstuffs could be found more easily.

Complex dysfunctions in the small and medium-sized towns in Romania and also in the most of the rural area emerged following the Romanian Revolution of 1989 which ended the communist regime and all its strictly controlled strings. The centrally-planned economies have been transformed into market-based systems. The general post-communist direction was towards decentralization, privatization and rapid urban change. Many industries were privatized but proved unprofitable on the free market and due to the lack of the entrepreneurial spirit of the population, the bankruptcy was inevitable. Cities without industry have begun to be depopulated and the destination of the migrants were their villages of origin. 


\section{Research questions}

On the background of a non-linear urban and rural development, in the historical context and also in the post-communist transition period, that has not yet ended in Romania, we want to encourage the holistic and interdisciplinary studies with cultural and social valences in urban and rural planning. Therefore the purpose of this research is to analyse, interpret and extract relevant information from historical illustrations about the appearance and characteristics of places which by continuous change have gained meaning for the inhabitants. The questions we would like to answer are: (1) to what extent the past is relevant to the planning of the future? (2) how much information can be gained from the observation of historical illustrations? and (3) how this information can be used in sustainable development plans? Through the case study, we will research a very little known town in Romania but very relevant through evolution and history for all the Transylvanian small and medium-sized towns and villages.

\section{THEORY AND METHODOLOGY}

Anthropologists John Payne Collier and Malcolm Collier have accurately explained, several decades ago, that "our cultural development, has been oriented to commanding nature by super-technology, carried out collectively through super-organization and specialization, making it difficult for us to accomplish holistic understanding" (Collier \& Collier, 1986, p. 6). This statement is even more relevant nowadays when it comes to observing and studying the characteristics of the whole in interdisciplinary areas such as urban and rural planning and one of the most important aspects remains how and by whom the major interdisciplinary projects are coordinated and approved. In Romania the General Urban Plans (P.U.G.) are mandatory for every rural or urban settlement and each plan is valid for ten years. According to the Law no. 350/2001, on Territorial and Urban Planning, the General Urban Plan has coordinating, regulatory and strategic character and is the main operational planning tool, providing the legal basis for the implementation of programs and actions in local development. The most important tasks of making and renewing these plans are assigned to the private Offices of Architecture and Urbanism that win the projects by auction, so the quality of these plans is not necessarily encouraged. Often those who develop the plans are not familiar with the territory under consideration, nor have the time and the necessary support to carry out thorough field researches, making legally impeccable plans but practically without any personalization. The plans are usually coordinated by architects with specialization in urbanism and before the legal approval, the plans are sent and investigated by about 10 to 20 public institutions with different specializations which offer positive or negative feedbacks. In this way the plans are not holistically investigated and understood and are not disputed either by residents, during public consultation, or by local councillors who often do not have the right specialization. For this reason, any action directed towards a planning that starts with local people and territory and gradually integrates into higher levels should be encouraged. Therefore through urban planning should be pursued not only the improvements of the environment in which people live, but also increasing the citizens' education and their sense of belonging to the place, where they live, work and which they transform according to their needs, until it becomes a home. In the past the sense of property and belonging to a place has motivated the population enough to organize themselves and defend their land, at present the same sense, but weaker, should be the driving force for a greater involvement of the citizens in urban aspects. In this case, the local history (widely debated in this article) could provide many distilled solutions. 


\section{The past and future relationship as yin and yang of planning}

Researching the genesis of settlements and how they evolved has a great practical and theoretical importance, given the fact that offers the planner the possibility to adopt projects and plans with a high degree of personalization in accordance with the local specificity. At the same time, "the genesis of a settlement imposes a selection of socio-economic and natural factors which ensures the viability of any rural or urban settlement, regardless of its size." (Cucu, 1974, p. 189) In this direction, the authors, Xavier Hernández, Pilar Comes and Jordi Ballonga (1990, pp. 1-61) have recreated the development stages in words and drawings of an imaginary city, named Barma, which is a typical city for the northern Mediterranean region. This city, even if never existed, it could have been located almost anywhere in the former Roman Empire and it is also very real considering that the streets, buildings, architecture and monuments are from other existing cities. Such a particularly complex study was conducted in order to pursue the development of our civilization, given that the word 'civilization' is derived from 'city'. Regarding the evolution of settlements in Romania there is a lack of specialized literature proving that this subject is treated superficially by both authorities and planners. Niedermaier $(2016, p .7)$ stated that in Romania and especially in Transylvania the demolitions of many historical buildings, during the communist period, followed by the incompetence of local authorities and the inadequate legal measures adopted since the Revolution of 1989, have led to the disregard of the specificities of different cities. Thus studying and observing the past of the cities and conducting historical studies related to urban plans by qualified specialists represents the main way to preserve the local identity of the Transylvanian cities. What citizens feel and how they relate to a foreign (Saxon, Szekler, Hungarian, etc.) built heritage and common history is also important. It is relevant to mention that the most significant identity elements of the Transylvanian settlements are given by the harmonious coexistence of Romanians, Saxons and Hungarians and the successful way by which these cohabiting communities have been involved in local development (Ciangă, 2016, p. 64, p. 163).

Causes and solutions for many problems of the Transylvanian settlements can be found in the past, except for a few cities whose spheres of influence exceeds the national border, most of the settlements are dependent on their geographic position and especially on the natural conditions that supported the emergence of different urban functions. Therefore, researching the functions of different settlements "must necessarily be done in accordance with the geographic position that corresponds to these functions" (Beaujeu-Garnier \& Chabot, 1971, p. 117). For example, in the case study of the small town of Rupea, it can be noticed that numerous factories built during the industrialization, imposed by the communist regime, proved to be unprofitable after the fall of the regime and today they form the typical brownfield areas with industrial ruins. The only branches of the industry that have survived or reborn are those based on a natural evolution, in accordance with the resources of the local territory and which have become competitive on the free market. Given that Rupea was raised to the rank of a town only in 1950, even though it has been the administrative centre of the region 'Scaunul Rupea' for centuries, it remained a centre of sales of agricultural products during the weekly fairs, acquiring a specialization on agriculture and food industry, especially buffalo milk products.

Similar to the town of Rupea, most settlements in Romania have entered a long period of decline after the fall of the communist regime, caused primarily by the lack of jobs that led to labour migration abroad or in the few thriving urban centres. Starting with the new millennium and Romania's Integration in the European Union in 2007, the west-European model was adopted and a long remodelling process of the national economy and political authority has begun, a process that begins to be reflected in more deprived areas of Romania. 


\section{Collecting, identifying and dating postcards}

According to Grix (2001, pp. 81-82) when the research is based on archives or documents, the researcher should be "fully aware of the origins, purpose and original audience" of those documents. The background aspects can be both necessary and relevant as long as they are providing substantiation and veracity to the research. These issues become even more significant within photographic interpretation as part of the indirect observation of visual materials (photographs, postcards, lithographs, drawings and other illustrations) made by others. In this case the authors can leave their mark of subjectivity on the visual materials, taking into account that their personality, specialization, interests and other information about the authors (behind the image) are increasing the subjectivity of the qualitative researches based on interpretation. Thus, the main role of the interpreter is to reduce as much as possible the subjectivity of the research by increasing the veracity of the interpretations (Maroși, 2015, p. 110).

Old official and private documents which can be the subject of urban history research are primarily documents issued by the local governments in the past, such as property deeds or land lease agreements but also legal acts and even testaments which may include certain peculiarities of some issues or aspects of the administration at those times. Along with these valuable documents, often in the agitated past, money, letters, passports, postcards and pictures have been hidden in the old households and sometimes can be discovered only after renovations or demolitions in attics, walls, fake chimneys or under floors and stairs (Figure 1).
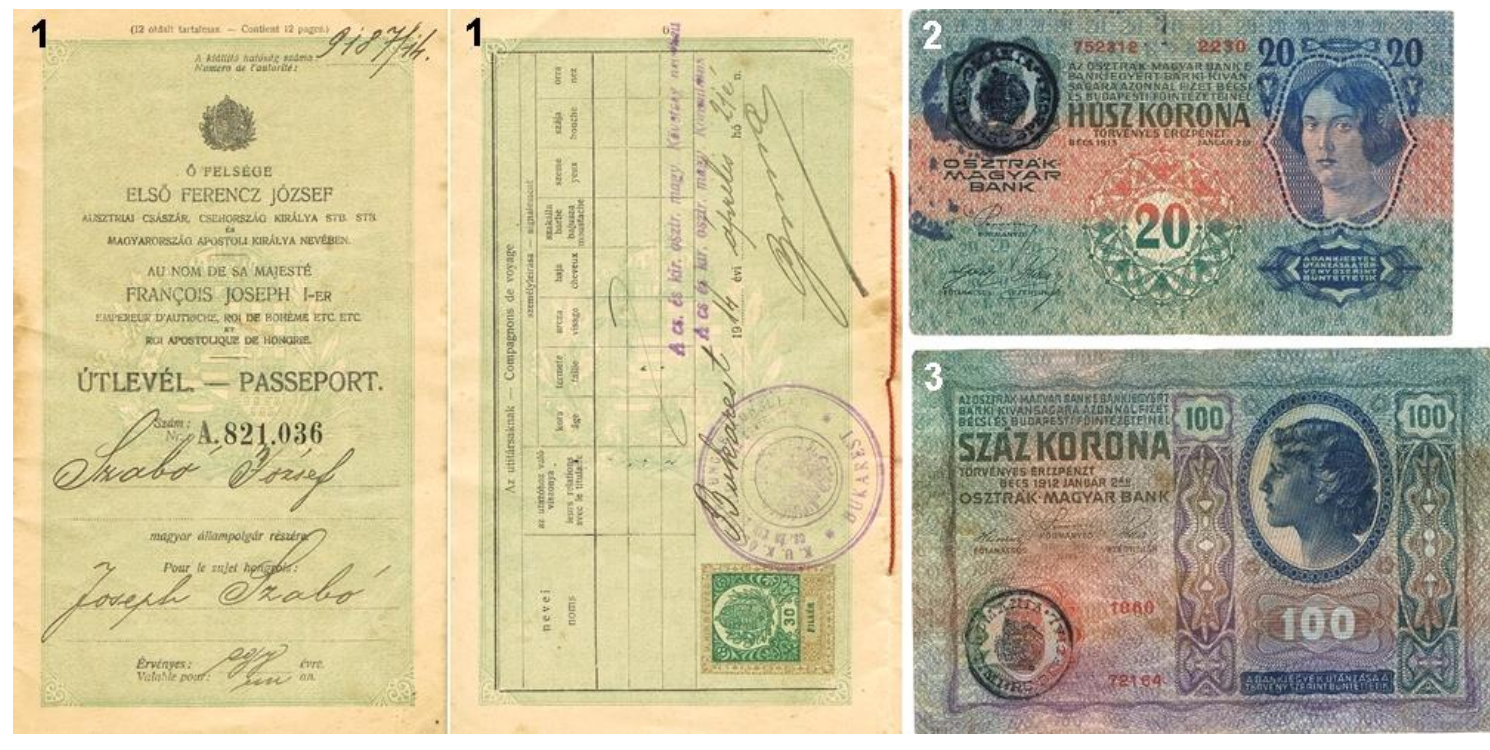

Figure 1: Historical documents hidden, preserved and discovered in old houses, in the region of Rupea, 1 - A passport from the Austro-Hungarian Empire (last used in 1914), 2 and 3 - Over-stamped Austro-Hungarian krone banknotes, used in the Kingdom of Romania after 1919.

\section{The Personal Collection of Zoltan MAROȘI}

In many cases, these old documents belonged to people who are not related to the current owners, so the documents are sold or donated to local collectors or to other people passionate about history. The electronic commerce websites, where people can put certain products on sale and online antique shops also encourages the search and collection of valuable historical documents. For urban history and planning more relevant are the postcards that illustrates landscapes or scenes from a town or region, from a particular time in history. This illustrations are very important as they are, often, the only images professionally made and preserved. 
For the walled cities and towns of Transylvania - as a peripheral region of the more advanced West, the technology of photography has become available late and that is why the $19^{\text {th }}$ century photographs are very rare. More than that, according to Borcoman (2010, p. 35) the streets of Rupea (as in other cities and towns) could be photographed only by obtaining the written authorization or permission from the local administration (as a measure against sabotage or espionage, inherited from the past). Therefore photographs could be made only in special workshops and only by professionals, making the photographs with urban themes and views, from the beginning of the $20^{\text {th }}$ century, even rarer. A boom of urban photographs as well as drawings and sketches of famous artists, will occur only during the interwar period.

Lithographs, drawings, engravings and other historical illustrations older than photographs are also important when they are completing a specific collection with reference to the same place. For our case study, Rupea (also known under the names of Reps, Köhalom, and Cohalm) has several official illustrations in the form of postcards or lithographs, covering a long period of time and capturing many changes in the appearance and functionality of the town's centre (Figure 2).
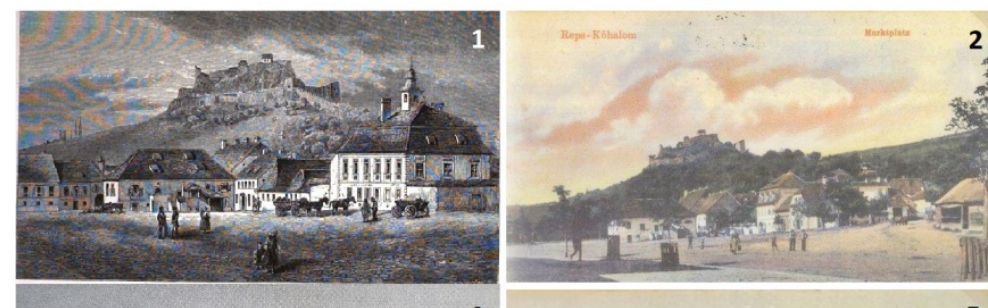

4

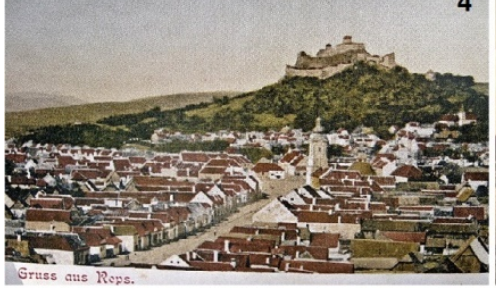

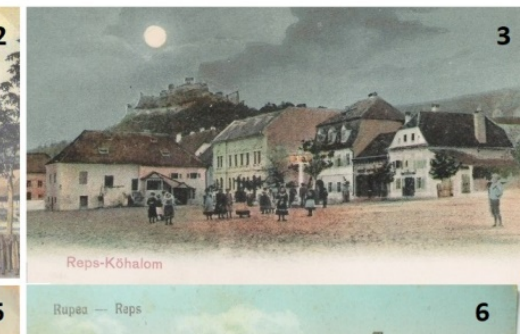

(1)

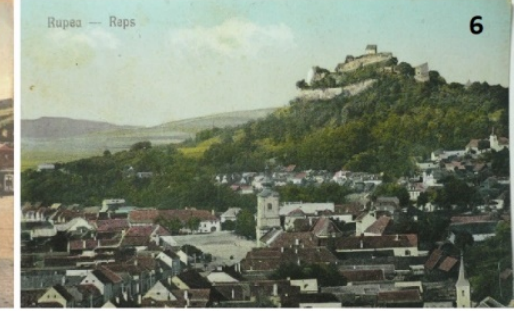

Figure 2: Postcards illustrating the town of Rupea from the same angle and in chronological order, 1 - Lithograph on Reps by G. Pearson 1851 (Boner, 1865, p. 244), 2 - Postcard on Reps- Kőhalom approx.

1900, 3 - Postcard commemorating the first public gas lighting in Reps- Kőhalom approx. 1910,

4 - Postcard with greetings "Gruss aus Reps" before the First World War, 5 and 6 Postcards on RepsKőhalom-Cohalm-Rupea from the interwar period.

The Personal Collection of Zoltan MAROȘI

In most cases, very old images are hard to locate due to the many changes that have occurred with the time to the appearance of the settlements, yet local monuments and landmarks, by their age and visibility, remains accurate reference points for localization. In some cases, a collection of chronologically arranged illustrations, including the same monuments and landmarks, are used to carry out History and Archaeological Study as part of urban planning documentations, necessary for the protection of the built heritage. In this case, Rupea Fortress according to Maroși (2017, pp. 31-46) and Borcoman (2010, pp. 17-28) is not only a visible landmark which has dominated the town for many centuries, but it is also an element of local identity, recognized by all the citizens as a symbol or brand of the town, associating the stronghold's image and shape with the town's name (the etymology of the names Rupea, Reps, Kőhalom and Cohalm derives from "mound of rocks" or "cliff"). Carefully examining the buildings in the illustrations, sometimes using a magnifying glass, may lead to the detection of details of great importance for dating the images and also regarding the building's function and even about their dimensions, construction styles, architecture and evolution. 
The names of settlements, especially in multicultural regions such as Transylvania, provides clues both for identifying and dating postcards. In Figure 2, it is highlighted that Pearson's Lithograph made in 1860s is named Reps, which is the German name of Rupea and during the Habsburg Empire it was the town's official name. After the Austro-Hungarian Compromise of 1867 and the birth of the Austro-Hungarian Empire, besides the name of Reps the Hungarian name Köhalom also began to be used once again given that Transylvania became part of the Kingdom of Hungary. Postcards inscribed with both names Reps-Köhalom (without the Romanian name Rupea) are definitely printed in the dualist period. After the First World War and the unification of Transylvania with the Kingdom of Romania in 1918 the Romanian names Cohalm (adaptation from Köhalom) and Rupea began to be used on Postcards, gradually replacing completely the Hungarian name. Therefore the official documents and the inscribed illustrations can be easily categorized in the three important periods of the Transylvanian history. Researching the postcards in details, the time interval in which they were assumed to have been used can be reduced. The exact date of the illustrations or postcards and other background information about the author or the print shop can be rarely obtained, with more chances when the documents are commemorating an event or have been used for special occasions.

Circulated postcards even if they are worn out they are easier to be dated and identified due to the postmarks which are applied along with the date and place, where and when the item got into the care of the postal service. However the information provided by postmarks should not always be taken for granted as long as the item (or illustration) may be much older.

Other modalities of dating and researching postcards are based on the use of a scanner with high optical density and resolution (in our case a $360 \mathrm{dpi} / \mathrm{ppi} \mathrm{scanner} \mathrm{was} \mathrm{used)} \mathrm{which} \mathrm{allows} \mathrm{a}$ strong image magnification and observation of the paper texture and image printing technique, providing clues about the time and place of the object's production. A magnifying glass would also help in this process as well, as in researching some elements that have been captured in the picture, such as: the clothing style of the inhabitants, the technology of the era (Figure 3 ) and even lost elements of architecture, of great importance for the monuments' restorations.

\section{Interpretation of postcards between utility and subjectivity}

Interpretation of visual images (or indirect observation) is part of the qualitative methodologies family and as long as it is done manually, by a researcher, is a subjective process, allowing the researcher to be as subjective as possible. In the production of visual materials such as lithographs, photographs, postcards, posters, drawings and other illustrations, there is also a second source of subjectivity, given by the authors of these images. Thus, the information behind the image becomes relevant to the researcher and usually refers to the purposes, intent, profession, personality and preparation of the interpreted image's author (Maroși, 2015, p. 110). This background information is rarely known, especially in the case of old photographs or postcards and the only way to check the accuracy of these images is to compare them with others, better known and with the same age. According to Bartram (2010, p. 137), all the information about the authors of the researched visual materials, including the social identity markers, are relevant and it influences the final results of the interpretation because the same image can be captured in different ways, to meet the author's purposes. For example, an image captured by an artist who aims to highlight the beauty or to expresses personal emotions or feelings (even with the price of altering the reality) is different from the same picture captured by a passionate of architecture and professional photographer who is very attentive to details. In the same way, the same personal information about the researcher can influence the results. 
Accepting that the interpretation of images is a subjective process based on illustrations and images made by different authors in different periods of time and which rarely come in contact with the interpreter or the researcher, it is relevant to point out that the aim of a qualitative research is not necessarily to mirror or to simulate the reality, which is perceived differently by each individual. Each individual creates his own reality based on its own perception, according to the methodological solipsism idea (Audi, 1999, p. 261, 861), but without sinking in its extreme conceptual attitude, it can be assumed that researching the perceived reality is an another way towards knowing and understanding the independent (objective) reality. Thereby, in qualitative researches is accepted that the psychological reality of an individual cannot be fully known or measured and the question "how subjective are the interpretations?" loses its relevance. Ratner (2008, p. 841) considers that the qualitative researcher role should be to outline an impression about a subjective reality, without questioning its degree of representativeness to the objective reality, in other words the researcher should accept the reality of an individual as an object of study and its role consists in validating the interpretations and giving meaning to them.

In the interpretation of postcards, or other visual images, there is no clear and universal step by step methodology to follow, it is more about blending, personalizing, and adapting multiple methods according to the research objectives. In this situation it is preferable to abandon the rigidity imposed by a framework and embracing a 'non-prescriptive' methodology, which is not popular among researchers, yet this unpredictability is "[o]ne of the most stimulating things about interpreting visual imagery" (Bartram, 2010, p. 132). In our case study, the objectives are to observe and to research the stages of evolution of Rupea town's historical centre, and for this purpose one of the oldest lithographs (Figure 3) was chosen as a key for the interpretation.
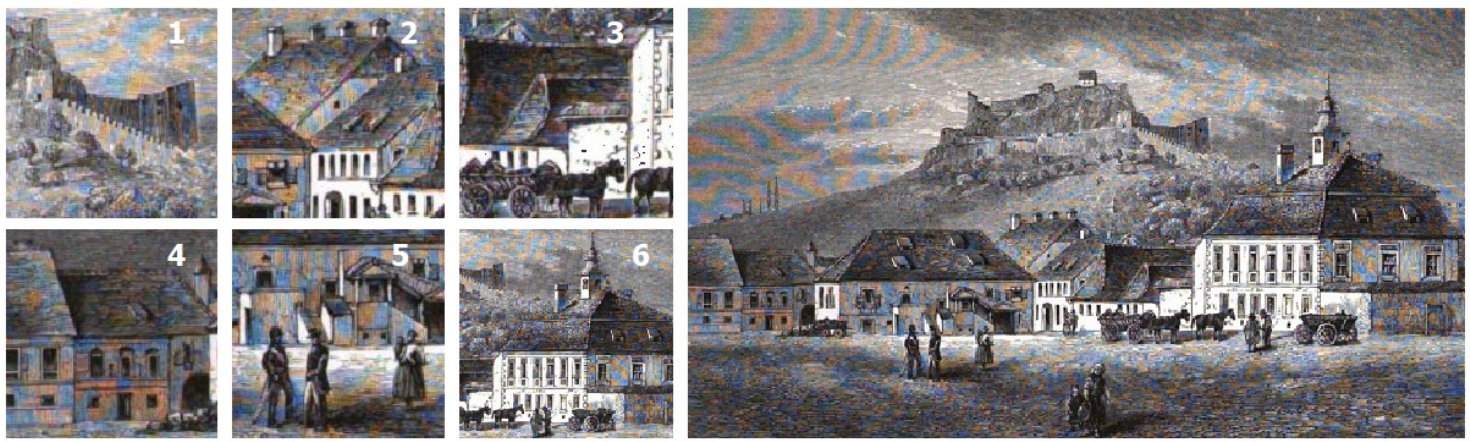

Figure 3: Lithograph on Reps - wood engraving by G. Pearson (published in Boner, 1865, p. 244)

1 - The original merlons of the stronghold, 2 - The building that is currently occupied by the local police station, 3 - Wooden cart wheels, 4- Buildings preserved to date, 5 - Imperial and Royal Hussars, $6-\mathrm{A}$ building with an important function demolished in the first decade of the $20^{\text {th }}$ century

The Personal Collection of Zoltan MAROȘI

By observing Pearson's lithography on Reps (Figure 3) made in the 1860s the only element of reference, easily identifiable by the local population, is the Fortress of Rupea. The buildings in the foreground and the big market place have been replaced in the current landscape with a park. Verifying the illustration veracity has been achieved with relative ease considering that the oldest representation of Rupea, made by Ludwig Schuller in 1851 and currently exhibited at the Brukenthal National Museum from Sibiu, can be easily compared with the analysed image. Both images contain very similar architectural details. The interpretation began by dividing the image shown in the lithography into three parts: background, middleground and foreground, depending on the horizon line and the distance from the viewer. In this way the observation can be better organized and also the collected information can be sorted into tables. 
The background of the lithography and of each postcard chosen according to the objectives of this research, is given by the iconic Fortress of Rupea, occupying a strategic position on the basalt cliff, 582 meters above the sea level or 120 meters above the nearby town centre. The fortress was rehabilitated and opened to visitors in June 2013, after decades of degradation and currently has a great popularity among tourists even though the rehabilitation process has sparked controversy among archaeologists, historians, architects and other specialists as described and analysed by Maroși (2017, pp. 31-46). The basalt cliff is a natural monument and also a protected geological area (IUCN Category III) with an area of 9 hectares which together with the fortress form an unmistakable skyline, a blend of natural beauty and human ingenuity.

More relevant details regarding the fortress are the merlons of its eastern wall which have not been preserved (Figure 3.1) and about which no written records have been found. There have been debates on the form of the merlons, if they were rounded like those on the southern wall or square shaped like those on the western wall, these illustrations being the only information left behind and a good starting point for specialists interested in medieval fortifications. To facilitate the comparison between other visual images and highlighting of some details, the original lithography was redrawn using the technology that is available to us (Figure 4).

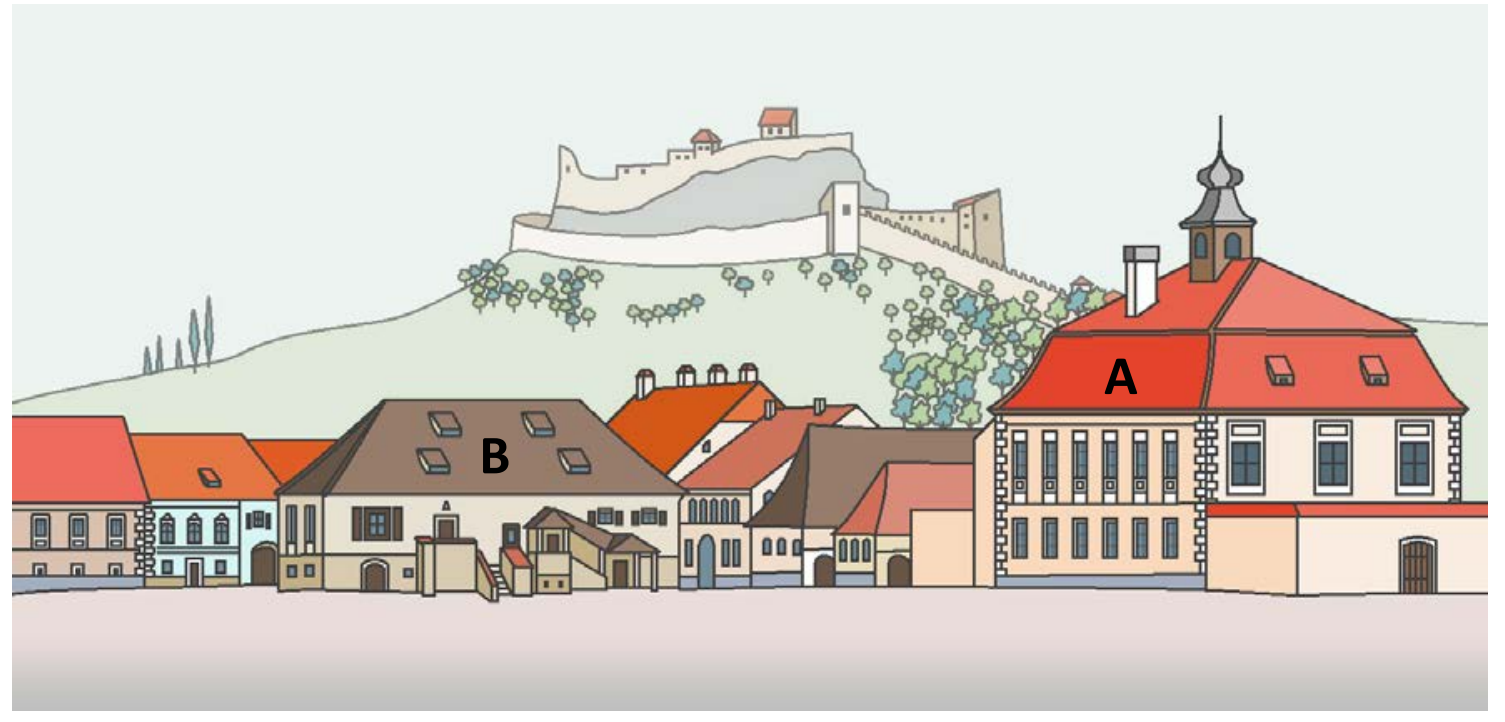

Figure 4: Redrawing the Lithograph on Reps by G. Pearson (published in Boner, 1865, p. 244)

Drawing by Zoltan MAROȘI, 2018

As it was detailed in Maroși $(2016$, p. 49, 53) redrawing of several historical illustrations in urban researches may be highly relevant for the following reasons: (1) time is corrosive in terms of preserving information within cultural artefacts and therefore, by redrawing, the historical information will be kept in circulation for future investigations or interpretations; (2) when the historical illustrations are used to obtain more information from the local population, redrawings would be easier to perceive because of the more accurate forms and added colours which together express the space more clearly, giving new life to old drawings, postcards or photographs; (3) a redrawn illustration will enable the possibilities to edit the properties of the digital drawn lines and of the colours for a better effect of space, facilitating overlapping and comparison with other redrawn illustrations and also the possibility of multiplying and completing the original visual image with any other information found from other sources. As a methodological part of a complex interpretation process is also the investigation board on which the visual information (postcards, lithographs, maps, etc.) can be organized into a highly descriptive collage. 

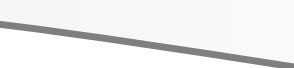

\section{-}

\section{Interpretation of postcards as an iconography of evolution}

The identification, description, and the interpretation of visual images (especially paintings) in art history, is called iconography. When more related images are placed in chronological order and express an evolution that can be studied or it is somehow relevant, then it is called informally an iconography of evolution ("Iconography", 2014). Although the interpretation in scientific researches is more accurate and cannot be called iconography, a word that also has a religious connotation, the principles are the same. In the Rupea case study it is very important to sift through all the information that can be obtained from postcards given that there is no written information about the evolution of this small town or about its built heritage (monuments).

The next identified postcard (Figure 5.1) which has the same angle and observation point as the key role lithography, illustrates a changed landscape, captured several decades after the oldest image of Rupea town. The postcard is not dated but a clear indication of the time difference is given by the afforestation of the Fortress Hill compared to the previous lithography which also indicates the loss of the defensive function of the fortress and the lack of maintenance. Another indication is given by the demolition of the large administrative building from the foreground of the lithography (Figure 4, building A). The function of the building is not known exactly, however it was deduced based on the dimensions and its central position in the square.

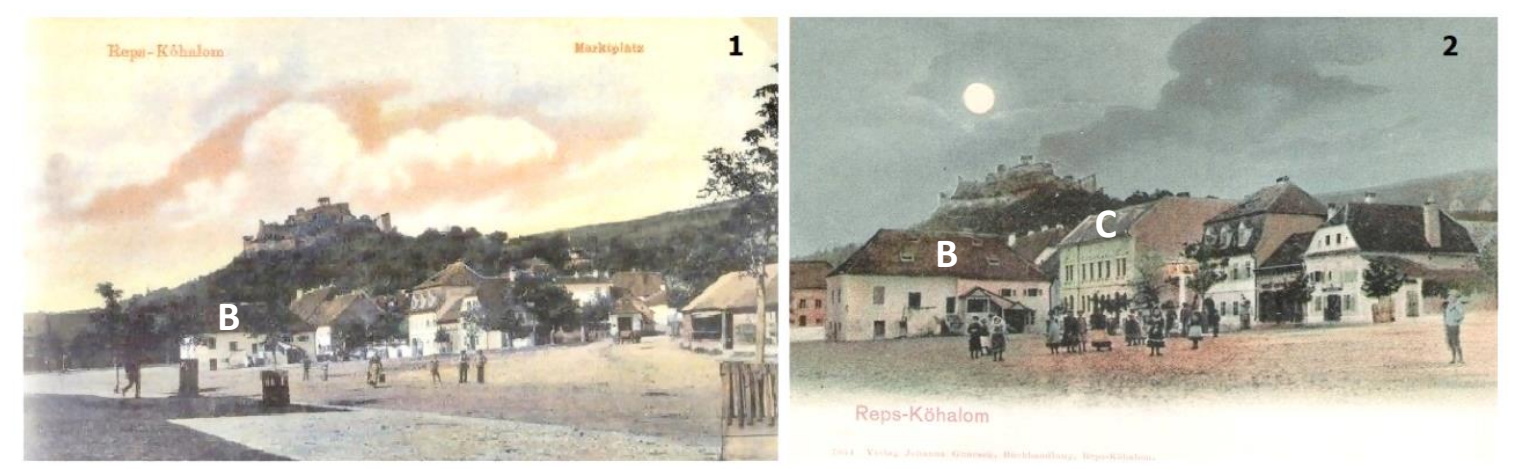

Figure 5: Postcards with view on Reps-Köhalom during the Austro-Hungarian administration

1 - Postcard with a morning landscape, as suggested by the shadows on the ground, cca. 1900-1909, 2 - Postcard commemorating the first public gas lighting, approx. 1910 (Borcoman, 2010)

The Personal Collection of Zoltan MAROȘI

According to Borcoman (2010, p. 67) during the Habsburg Empire the town of Rupea, as the centre of one of the autonomous Saxon regions known as chairs or seats (The Chair of Rupea, known in German as "Repser Stuhl" and in Hungarian as "Köhalom szék", also visible on the Josephinian Land Survey) had three important officials: judex regis which was subject only to the King of Hungary, judex sedis or judex terrestris (the prefect of the chair as a region) and the town's major. Building A was probably the seat of the judex officials, the administrative centre of the region and also the court. Demolition of that building would indicate an administrative reform which means removing the authority of the judex officials which has happened after the Austro-Hungarian Compromise of 1867 and the formation of the Austro-Hungarian Empire. The postcard from the Figure 5.1 was probably made after the opening of the first local hospital and the curative baths in 1902, Rupea becoming a spa centre. A detail is given in the foreground by a woman who carries water in two buckets, confirming that Rupea really had problems with drinking water, the small river Kozd run dry every summer and the local wells could not provide the necessary water for all the domestic animals. There are also cases where some wells have become salty, due to salt reserves close to the surface. 
The next postcard (Figure 5.2) was made to commemorate the first public gas lighting and it was dated by Borcoman (2010, Fig. 18) as an image taken before 1890, however the town hall used today also appears in the picture and it is known that this building (Figure 5, building $\mathrm{C}$ ) was built after the demolition of the older administrative buildings, between the years 1906-1909, during the Austro-Hungarian Empire reforms. This unusual night landscape, if we consider the limits of the photography technology of that time, it is relevant not only because captures the moment of the first public lighting, but also because it is the last image of the town's centre before the First World War, illustrating both the local Saxon population dressed in traditional clothing and the buildings that still exist today (except for the building B, Figure 5).

\section{Interpretation of postcards and the comparison method}

After the First World War postcards have ceased to be printed for a longer period of time, the only exceptions are the economic variants of old images reprinted in black and white. Switching to a different political context in which Reps becomes Rupea within the Kingdom of Romania did not lead to visible changes in the architecture of the centre, there have only been demolished buildings that lost their function (the communal warehouse, building B). Moreover, the traditional demographic structures and administration of the town were affected, but in general, until the administrative reorganization from 1925 the town was experiencing an economic stagnation. This situation is very well reflected in the postcards compared in Figure 6.
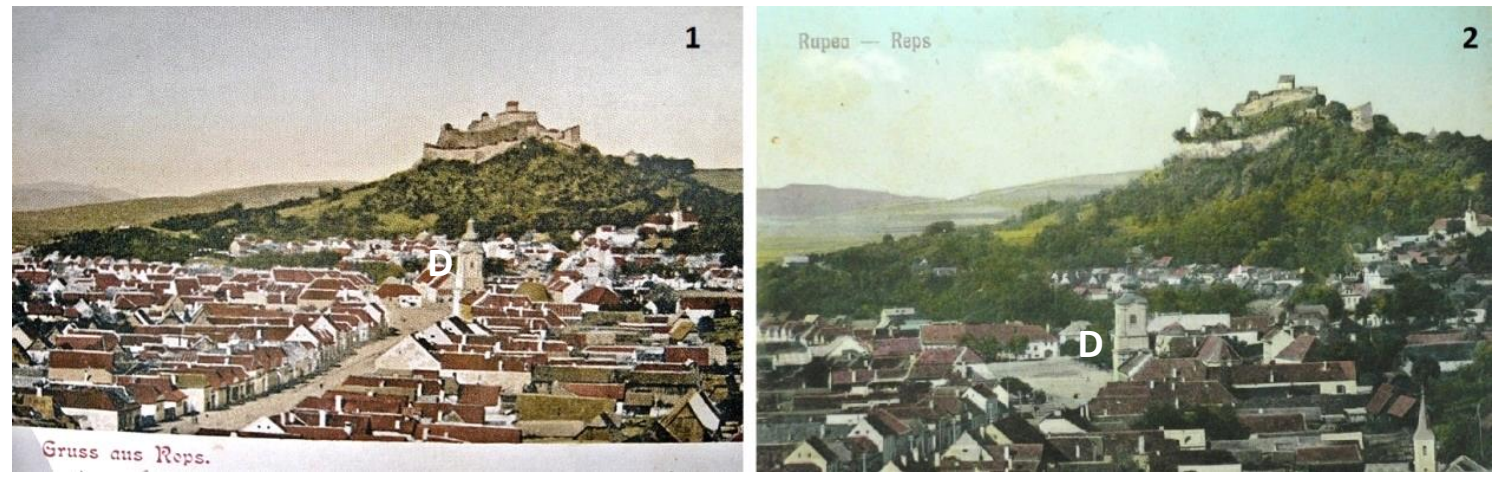

Figure 6: Two bird's eye view postcards on Reps-Rupea showing by comparison a few changes before and after the First World War, images taken before 1925

1 - Postcard with the main street of Reps (Rupea) after 1910 (Borcoman, 2010)

2 - Postcard made after the union of Transylvania with the Romanian Kingdom

\section{The Personal Collection of Zoltan MAROȘI}

Among the few differences between the two compared postcards can be observed the clock tower in Baroque style (known today as the Saxon's Tower, building D, Figure 6) built in 1782 as an appendix to the nearby evangelical church in Gothic style ( $14^{\text {th }}$ century). This tower was the tallest building in the town until the 70s and represented the pride of the Saxon population which is why the state of the building reflects the social and economic situation of the Saxons. In Figure 6.2 the tower is in a more neglected condition as well as the fortress, then almost completely covered with vegetation. The central square behind the tower was still used as market place (with fees charged by the Town Hall). During the First World War Rupea was very close to the south-eastern frontier of the Austro-Hungarian Empire (Figure 1.1) and hosted numerous barracks for soldiers. A Romanian soldier and novelist named Camil Petrescu described the town of that period as follows: "a town with wide country streets, Saxon houses with tall and closed gates and with windows like those of a fortress. A large square in the middle - maybe for Sunday fairs. Seated at the meeting of two valleys..." (Petrescu, 1997, pp. 167-172). 
In the interwar period, the modernization process of Romania began by rewriting the constitution and has continued through numerous reforms which aimed a synchronization with the Occident. Any remnants of medieval organizations have been abolished, especially those of the Saxons, Szeklers and the Hungarian nobles and landowners. Many officials, civil servants and principals, especially Hungarians, were replaced by Romanians and step by step the Hungarian names were removed from public places (also the older names of the settlements, as can be seen on postcards).

The following two postcards presented in Figure 7 are depicting buildings that still exist today, there have been no major changes since then in these alignments of buildings. In the first postcard (Figure 7.1) the large market and the buildings with colourful facades are being seen, well-maintained and with different commercial spaces on the ground floor. At that time the Café Zerbes was opened and it was a famous place in the area, there are postcards dedicated exclusively to this café. The town functioned as a spa resort and hosted weekly fairs (which are still held every Friday). Another important event occurred in 1921, under the patronage of King Ferdinand and Queen Mary of Romania, the act of laying the foundation of a new state gymnasium (today St. O. losif High School) took place. The high school building (building E, Figure 7) was erected after the Great Depression, shortly before the Second World War and opened only in 1952, over time it became one of the local landmarks, under the fortress.

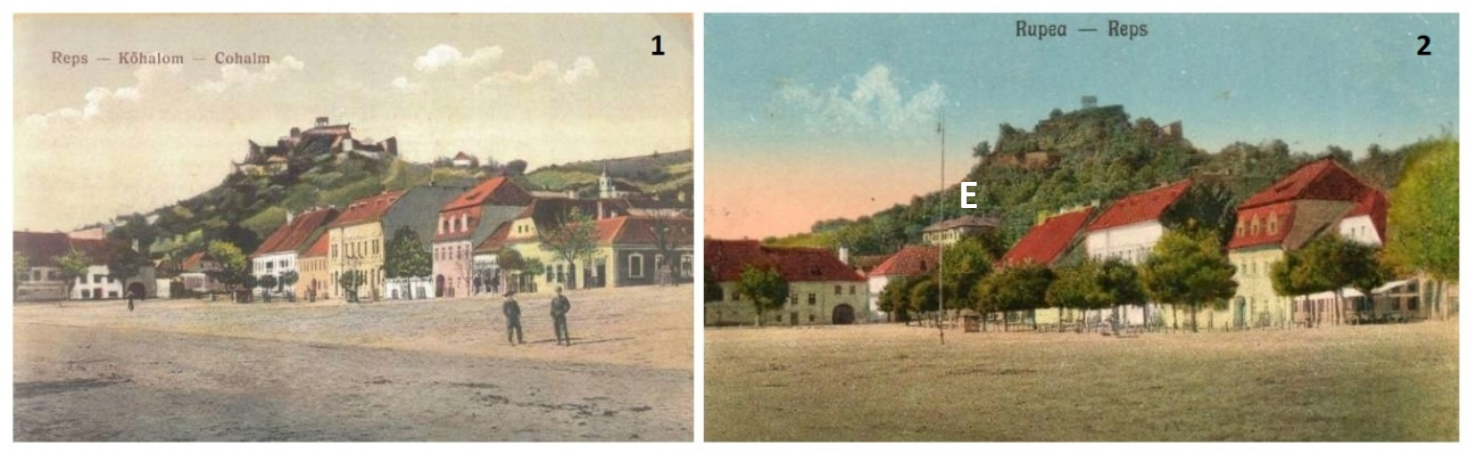

Figure 7: Postcards with view on Reps-Kőhalom-Cohalm and later Rupea in the first integration period into the Kingdom of Romania (the interwar period)

1 - cca. 1922, 2 - The first appearance of the high school building, after 1935

The Personal Collection of Zoltan MAROȘI

One of the most important aspects of modernization was the introduction of electricity into the rural settlements of Romania. Although in the case of Rupea it is not known the exact date of this important event, a few official documents from local archives reminds about the first public power plant opened in Brasov (the nearest regional city to Rupea) in 1930 and also about a written request from the Orthodox churches from Rupea to the local administration, in which it was requested the connection to the electricity grid with the expenses covered by the local budget, in 1938 (Borcoman, 2010, p. 45). In Figure 7.2, a power light pole appears for the first time in a postcard with view on Rupea, located in the middle of the square. Starting from this moment, in the urban landscape will appear, besides the aerial cables, large radio antennas on almost every house, as they appear on a few postcards. The first cars will begin to circulate among carts and the main streets will be paved with cobblestone. The central square will also be adapted for leisure activities, tree rows appears, providing the shade for terraces. During this period of time an important textile factory is established in the town and a new sanatorium is built, Rupea becoming a small medical centre for the nearby rural region, within a radius of 30 kilometres, there was no other accessible town with the minimum facilities. 
Rupea during the Socialist Republic of Romania

After the forced abdication of King Michael I of Romania in 1947, communism began to emerge and through all expropriations, nationalizations and collectivisations the goal of accomplishing the Soviet Union model of centrally planned economy was reached by the new government. The unrestricted management of all resources has allowed a rapid, coordinated, state-run industrialization and as a result the urban population has rapidly increased. In the case of Rupea, it became a town in 1951 and in twenty years of systematization the landscape was completely changed in the context of a rapid urbanization. Because there was no free market anymore, the central square lost its function and was transformed into a park, as it can be observed in Figure 8.1. In the background of the same postcard (Figure 8.F) a new residential neighbourhood with five-storey apartment blocks can be observed, apartments constructed after 1972-1973 and occupied (rented from the town hall) primarily by immigrants from rural areas.

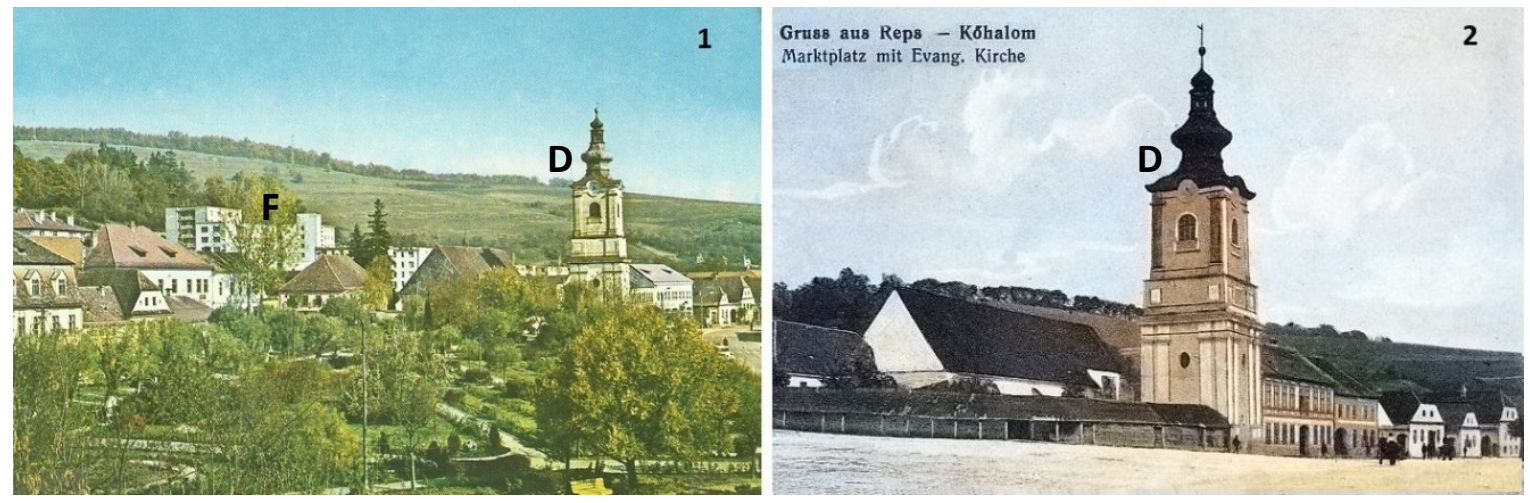

Figure 8: Postcards with view on the Saxon's Tower Rupea-Reps in different epochs

1 - Systematization in the communist time and the Central Park cca. 1970, 2 - cca. 1916

The Personal Collection of Zoltan MAROȘI

In the same communist architectural style, economic buildings from concrete and glass were built all over the town: a large hospital built in 1969 to serve the entire area, new school buildings, libraries, dormitories, cafeterias, restaurants and a cinema. Among the public utilities built, the most important was the water supply system, with a dam located $25 \mathrm{~km}$ east from Rupea, a sewage system (completely rebuilt with a sewage treatment plant in 2013) and a Local Transportation Base with garages and mechanical workshops to maintain a fleet of 235 trucks and 47 buses that were active on 20 routes, vehicles registered there in 1976 (Pantelimon, 1977, p. 72). At the same time, a textile and a carpet industry has been set up in Rupea, as well as one of the largest parquet factories from the country. The food industry has also been well developed (the only industry that has survived to date). Even if in short-term the communist government had unprecedented achievements, raising the well-being of the working class population, in the long run, all the major investments were not recovered from the factories' profits. The entire industry, after 1989 proved to be unprofitable and with many debts, gradually becoming bankrupt. The biggest problems in the post-communist period was probably the lack of entrepreneurial spirit of the population, still dependent on the state. The recovery period was very slow and is still ongoing, a long period of time the incomes have also came from demolitions and sales of derelict communist factories. Yet communism remains the period of large-scale constructions, the landscapes being dominated by construction sites and cranes, also visible in Figure 8.1, behind the Saxon's Tower. Small settlements, villages and towns such as Rupea had the biggest problems in the post-communist era because they have remained with an oversized and unnecessary infrastructure and without their traditional, stable economy. 


\section{RESULTS AND DISCUSSION}

Rupea is located in the centre of Romania (Brașov County, Transylvania) and it is in the category of very small towns, with a population below 10,000 inhabitants, which is the lower limit of a town to maintain its rank according to the laws. Even so, Rupea is not downgraded because it is the only town within a radius of $30 \mathrm{~km}$ in the north of Brasov County and provides, for the smaller nearby settlements, educational, sanitary and other public services. After 1989 and the dissolution of the communist government, Rupea (and almost all the smaller settlements) have entered a linear decline which was to be slowed by Romania's accession to the European Union in 2007. From that moment a few investments were initiated, such as the construction of the national road belt in the south of the town, modernizing and relocating the weekly market place and other matters pertaining to the European standards. Soon after that investors began to appear, and small factories were reopened (Transy/vania Lactate dairy products from buffalo milk - an industrial branch that also existed before communism). Although the food industry has begun to recover, the town started to focus on another specialization in the last 5 years, when Rupea was the beneficiary of a project financed by the 2007-2013 Regional Operational Programme (ROP) and the result was the rehabilitation of the Rupea fortress, completed in $15^{\text {th }}$ of June 2013 (Ilovan \& Maroși, 2015, p. 67). The number of visitors increased more than it was expected and the local economy has felt the impulse, among the local government priorities was to increase the number of tourists and especially the preservation of the built heritage.

\section{The evolution of the historic centre of Rupea}

During the communist period, there was no limit to systematization, even the local monuments or landmarks did not have the certainty of staying untouched. In the 1970s, there was even a plan to demolish Rupea fortress for the exploitation of the basalt cliff over which it was built and from which the name of the town derived, just to pave the town's streets as cheap as possible (Maroși, 2017, p. 36). Currently, each General Urban Plan has an attached documentation called History and Archaeological study which is made by architects, historians and archaeologists with the right of signature and approved by the Ministry of Culture. However, these documentation have a low degree of personalization and qualitatively weak, fact encouraged by the auctioning of these projects for private planning offices. Thus for very little known settlements, there are very few written records about buildings and other aspects of urbanism, motivating even more our approach in this article to use even postcards as valuable sources of information (Figure 9).
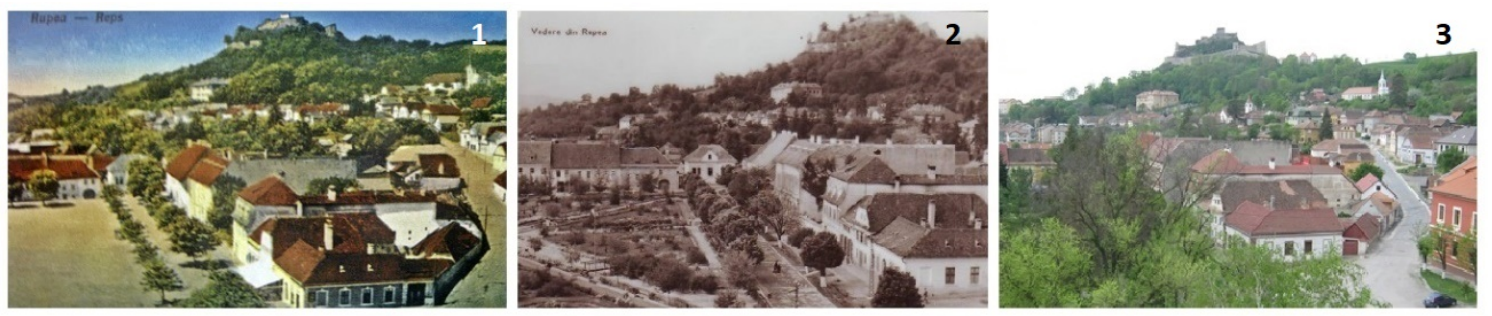

Figure 9: Rupea town's central square functional reconversion, 1 - postcard from 1930, 2 - postcard from 1969, 3 - photograph made in 2016 (Maroși, 2017, p. 44)

With regard to the historic centre, as stated by Niedermaier (2016, p. 164) the squares are a centralized element of every street network and according to several calculations, the surfaces of the squares seems to be in proportions with the total size of the colonized settlements or fortified towns from Transylvania (5-9\% of the built-up area) but only if we relate to their surface in the period before industrialization. The town has its genesis in the Saxon colonization period, fact supported by the town's proportions and configuration, with long plots, a central market, 
wide (oversized) streets and households next to each other in an organized form with traditional houses of the same style, but the identity and the feeling of the place almost disappeared because of the failure to observe several urban and architectural rules. In an attempt to discourage owners to make unapproved changes to their homes (most of them returned from abroad) the local administration has installed information panels about the local traditional architecture and several examples with good and bad practices in modernization of old houses. However, the town was gradually transformed into an architectural mosaic in which traditional and badly modified houses are mutually reducing their aesthetic value, creating a lack of "visual order of unity, proportion, scale, contrast, balance, rhythm. Ornament and decoration also have the capacity to unleash feelings, trigger reactions, feed the memory and stimulate the imagination" (Moughtin et al., 1999, p. 3). Although the inauguration of the fortress put the town on the tourist map of Romania, a landmark that promotes itself, being very visible from its strategic position, the town was limited to a transit tourism. Buses with tourists stop at the fortress but almost never visit the town below, which not only does not offer tourist services but it creates the impression of degradation and pauperization. Even if the local authorities have managed to put the main street (Republicii and Cetății St.) on the national patrimony list, in fact, there is no law and no local action group through which future renovation could be effectively coordinated or supervised.

In order to strengthen the local historical studies the results obtained from the interpretation of the postcards were completed by those shown in old maps, the Josephinian Land Survey conducted from 1763 to 1787 and many other drawings, journals and other personal documents. At present the town's centre is occupied by a park (Figure 10) which is highly appreciated by the local population, but only a few know that this place has been the old market, the heart of Rupea.
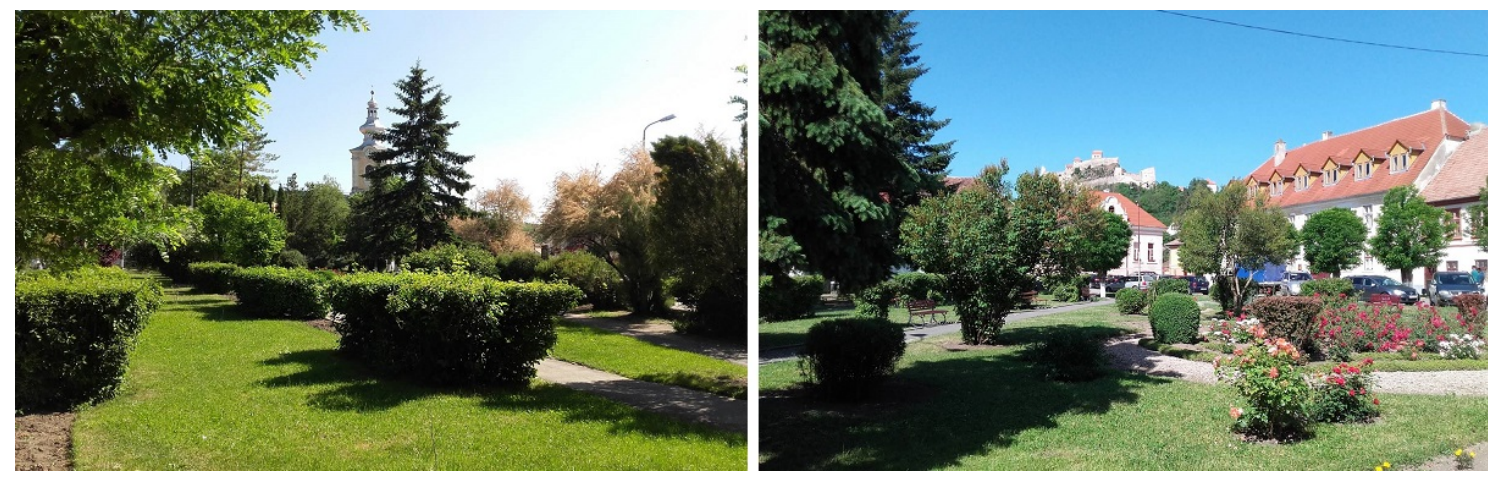

Figure 10: Rupea town's Central Park (the former square) also known as the Danny Huwe Park Photographs by Zoltan MAROȘI, 2018

To improve the urban landscape and increasing its attractiveness, the past is of utmost importance as long as it confers the identity of the place, something that can be experienced by visitors only in this unique place. To educate the local population and to awaken their interest and respect towards the built heritage, some thematic exhibitions with images explained from different periods, with possible redrawing and even 3D models could be very effective if they were funded by the local administration. Involvement of high school students and others who are interested in this project and in collaboration with students, teachers and experts from universities could bring the necessary practices in the town. An unfavourable aspect is also given by the concentration of the most researchers' attention on big cities of Transylvania, while small and medium-sized settlements are confronted with the most urgent problems. 
As was observed through postcards, the weekly fairs in Rupea took place, until the middle of the $20^{\text {th }}$ century in the central square, in front of the town hall and other administrative buildings, suggesting the importance of the town's commercial activity. The large size of this place (cca. 180 $x 60$ meters, or 10,800 sq. meters, Figure 12) currently occupied by the central park, indicates the importance of the fairs that took place in the town which was seated at the intersection of two important roads in the cardinal directions. Numerous craftsmen grouped in guilds together with merchants and their families settled in Rupea and left behind documents with their affairs.

After 1950 Rupea was raised to the rank of town and the new communist regime has introduced numerous changes in the cultural landscape. The fairs have been reduced in size and relocated in the more peripheral areas of the town. In the 1970s, the fairs began to reassert, especially those of the remaining farmers who were selling their agricultural products. According to the existing laws the farm animals fairs requires a sanitary protection area of minimum 500 meters from the built-up areas (Ministry of Health, 2014) which is why the fair has been moved again after 2010 to the south-eastern part of the town. This fair has remained a weekly event that animates the town (Figure 11) every Friday Rupea becoming the busiest settlement in the area. Yet, it is not an attraction for tourists because there is no strict strategy for organizing and promoting the events and also there are no entertainment activities for tourists.
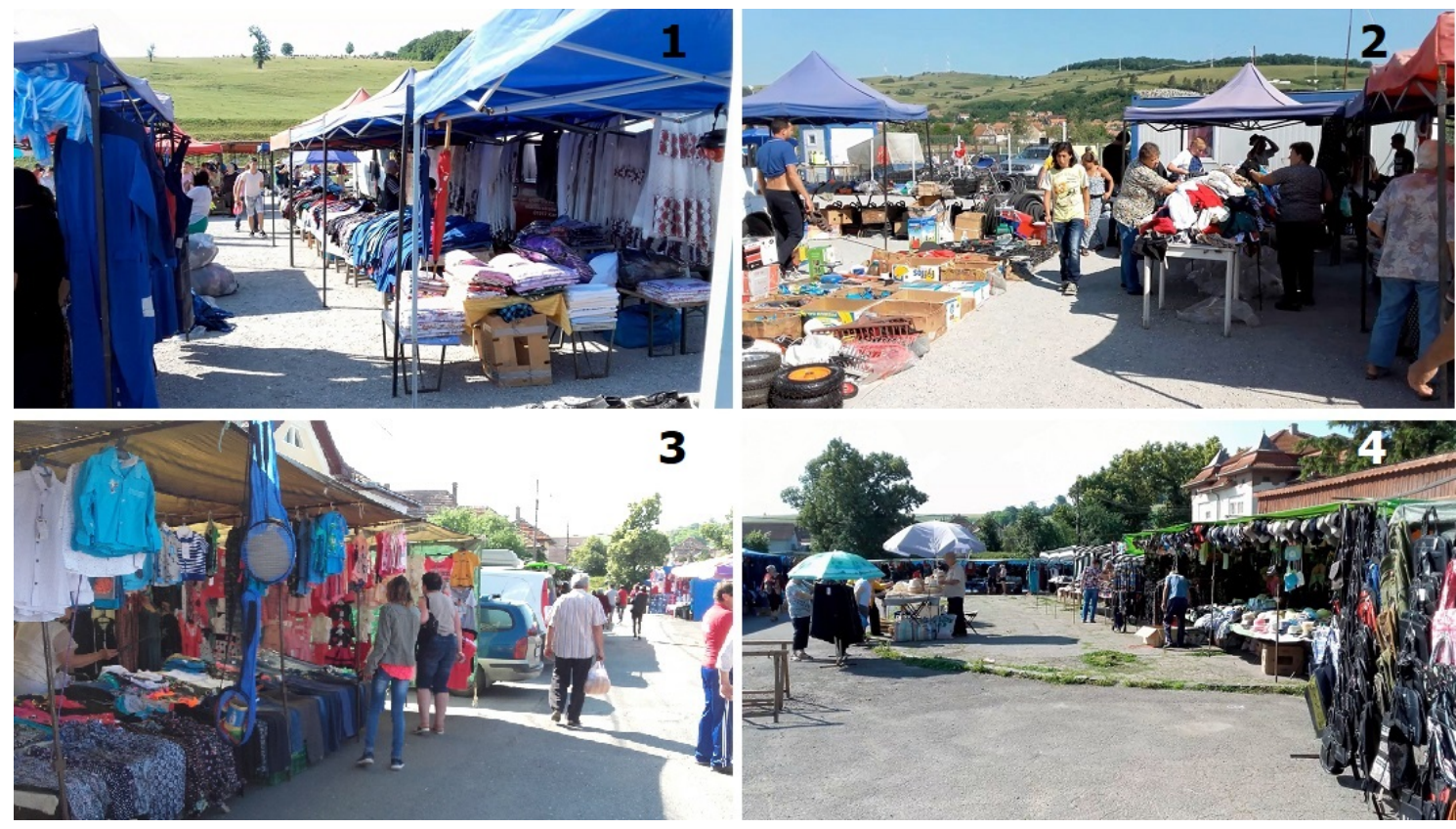

Figure 11: Rupea town's weekly fair, 1, 2 - the market outside the town, 3, 4-the old market Photographs by Zoltan MAROȘI, 2018

Since its inception, Rupea has been an important place to trade and this activity had so many influences that it shaped the centre of the town, the fair became an important part not only of the local identity but also of the settlement's history. According to Niedermaier (2016, pp. 332333) the traces of an older Szekler settlement are preserved through the urban configuration and by an old cemetery nearby the Evangelical Church. This settlement had a semi-oval market place (still visible near the north-eastern part of the central park, Figure 12) and it was relocated after the colonization with Germans in the place where the park currently exists. The entire Republicii Street was the commercial transit route connecting two important historical regions. 


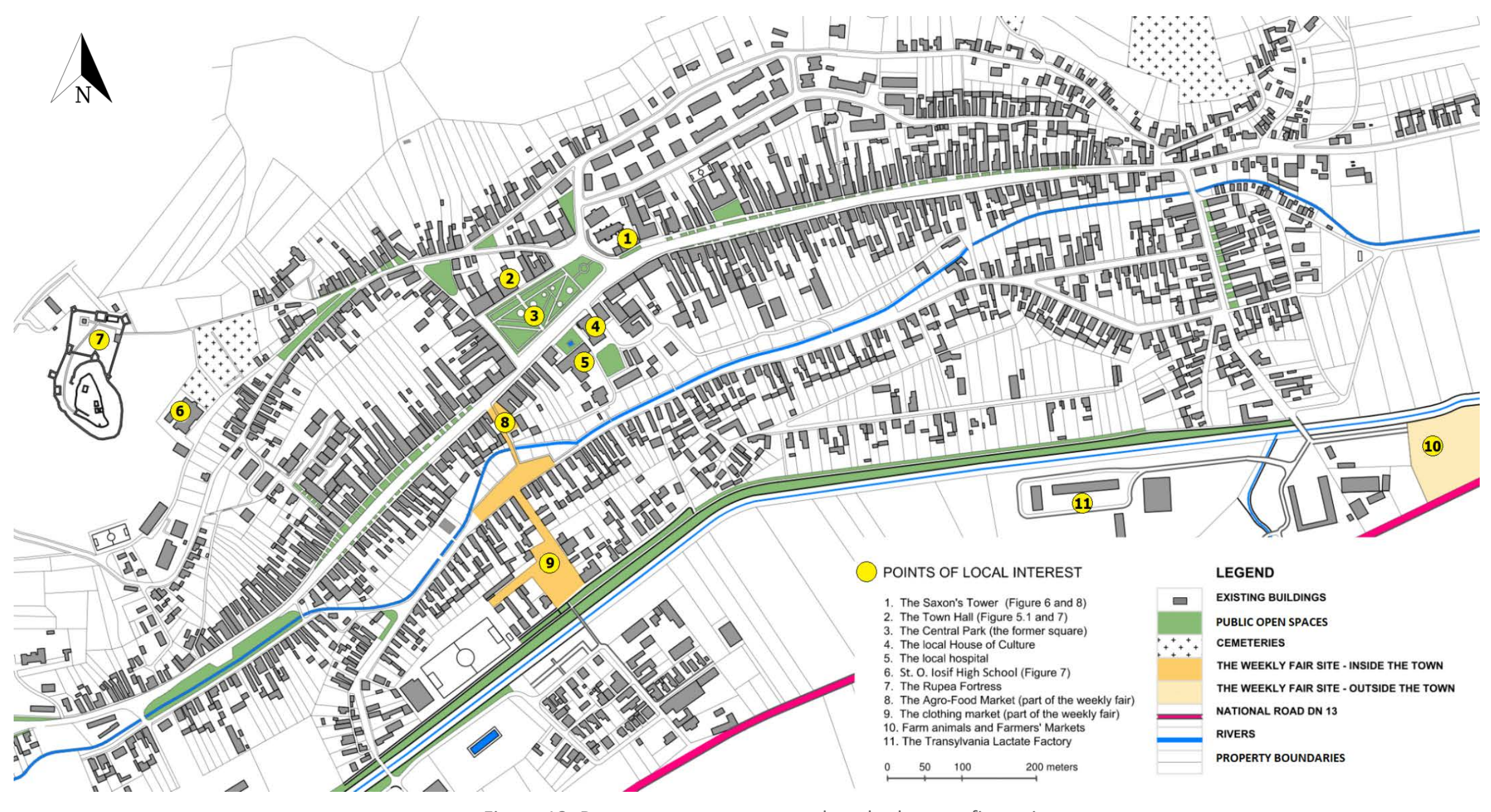

Figure 12: Rupea town street network and urban configuration Cartography by Zoltan MAROȘI, 2018 


\section{Regarding future research on the subject}

This article complements the research about Rupea Fortress, Representations of Local Identity through Landmarks: The Rehabilitation of Rupea Fortress, Romania (Maroși, 2017, pp. 31-46). In the circumstances of an ageing population and an intense rural exodus, the Transylvanian villages are going through a transition period and often in decline, reflecting the changes firstly in the local landscape. In February 2016 at an interval of one week, two towers of fortified churches (classified monuments) collapsed in the county of Brasov, Romania, one of them disappearing from the landscape for the first time in hundreds of years. These two Gothic churches, Roadeș (Radenthal) and Rotbav (Rothbach) close to Rupea, were built in the $14^{\text {th }}$ and $15^{\text {th }}$ centuries by the Saxon community and currently (without this community) they were left without financial support. Assessing the physical condition of the built heritage in rural areas of Transylvania will remain an open topic for the next research on the built heritage.

\section{CONCLUSIONS}

Through this research it was conducted for the first time an approach to the local urban history of Rupea town using unconventional information sources. Although very little is known about the town's detailed (personal) past and especially about it's built heritage, we have succeeded in highlighting the following issues by interpreting postcards: (1) identifying architectural elements that have disappeared at present and are very relevant for restorations (2) identifying important buildings about which there was no written information (3) placing in chronological order the information (and the dated postcards) regarding the evolution of the town (4) the correlation of the local history to the history of Transylvania and of Romania (5) presenting a holistic approach to the local development and (6) contributing to future History and Archaeological Studies as part of a sustainable development through conservation and protection of the built heritage.

This paper also has a methodological relevance given the fact that it explains and encourages the using of postcards in urban research, to obtain information when the traditional sources of written documents are missing or are insufficient. In this case, besides the town of Rupea, most of the smaller cities in Romania can be included. The questions we have answered, limited to the case of this research, are: (1) to what extent the past is relevant to the planning of the future? (2) how much information can be gained from the observation of historical illustrations? and (3) how this information can be used in sustainable development plans. The last question also covered the purpose of this approach, considering that Rupea is going through a transition period which is oriented towards the tourism specialization and the problems that currently exists with regard to its built heritage and its cultural landscape. In the current context of Rupea town's threatened built heritage and the specialization in tourism, this paper becomes highly relevant and by encouraging the use of postcards in the research of urban history it is also a methodological pioneering with great potential for Transylvania.

\section{On using the postcards included in this paper}

In Romania, according to Law no. 8 from the $14^{\text {th }}$ of March 1996, concerning the copyright and the related rights, Chapter 10, Article 85, Paragraph 2, photographs of letters, deeds, and documents of any kind, technical drawings and other such documents cannot benefit from the legal protection of copyright. http://www.cdep.ro/pls/legis/legis_pck.htp_act_text?idt=10396 Moreover, the author of this paper (Maroşi Zoltan) worked with postcards whose authors are not known, mentioning the source where they were published before if it was possible. 


\section{REFERENCES}

ANDREI, T. (coord.) (2018). Romanian Statistical Yearbook 2017. Bucharest: National Institute of Statistics.

AUDI, R. (ed.) (1999). The Cambridge Dictionary of Philosophy, $2^{\text {nd }}$ edition. Cambridge: Cambridge University Press.

BARTRAM, R. (2010). Geography and the Interpretation of Visual Imagery. In: CLIFFORD, N., FRENCH, S., \& VALENTINE, G. (eds.), Key Methods in Geography, $2^{\text {nd }}$ edition (pp. 131-140). London: SAGE.

BEAUJEU-GARNIER, J., \& CHABOT, G. (1971). Geografia Urbană [Urban Geography]. Bucharest: Editura Științifică.

BONER, C. (1865). Burgher Strongholds. In: BONER, C. (ed.), Transylvania: Its Products and Its People (pp. 228-247). London: Longmans, Green, Reader, and Dyer.

BORCOMAN, M. (2010). Aşezări transilvane. Rupea [Transylvanian Settlements. Rupea]. Cluj-Napoca: Editura Academiei Române. Centrul de Studii Transilvane.

CIANGĂ, I.-F. (2016). Peisajul urban în vedutismul transilvan [The Urban Landscape in Transylvanian Vedutism]. ClujNapoca: Risoprint.

COLLIER, J. P., \& COLLIER, M. (1986). Visual Anthropology. Photography as a Research Method. Albuquerque: University of New Mexico Press.

CUCU, V. (1974). Geografia populației și așezărilor omenești [Geography of Population and Human Settlements]. Bucharest: Editura Didactică și Pedagogică.

DRĂGOESCU, R. (2015). Anuarului Demografic al României [Demographical Yearbook of Romania]. Bucharest: Institutul Național de Statistică. Retrieved 28 March 2018, from http://www.insse.ro/cms/files/publicatii/pliante\%20statistice

GALLION, A. B., \& EISNER, S. (1980). The Urban Pattern: City Planning and Design. New York: D. Van Nostrand Co.

GRIX, J. (2001). Demystifying Postgraduate Research from Ma to PhD. Birmingham: University Press.

HERNÁNDEZ, X., COMES, P., \& BALLONGA, J. (1990). A Town through History. Sussex: Wayland Publishers Ltd.

ILOVAN, O.-R., \& MAROȘI, Z. (2015). Leadership and Regeneration of the Transylvanian Villages in the Region of Rupea. In: BANINI, T., \& INCH F. (eds.), Semestrale di Studi e Ricerche di Geografia, 27(1), 63-70.

Law no. 350/6 July 2001, on Territorial Planning and Urbanism Published in M.Of. nr. 373/10 iul. 2001

MAROȘI, Z. (2015). The Relevance of Using Photographs in Geographical Research. Geographia Napocensis, 9(1), 109-119.

MAROȘI, Z. (2016). Redrawing Historical Illustrations in Research of Genuine Urban Features. Territorial Identity and Development, 1(1), 45-58.

MAROȘI, Z. (2017). Representations of Local Identity through Landmarks: The Rehabilitation of Rupea Fortress, Romania. Territorial Identity and Development, 1(2), 31-46.

MINISTRY OF HEALTH (2014). Ordin nr. 119/2014 pentru aprobarea Normelor de igiena si sanatate publica privind mediul de viata al populatiei [Order no. 119/2014 for Approving the Norms of Hygiene and Public Health Concerning the Population's Living Environment]. In Monitorul Oficial, Partea I nr. 127 din 21 februarie 2014.

MOUGHTIN, C., OC, T., \& TIESDELL, S. (1999). Urban Design: Ornament and Decoration, $2^{\text {nd }}$ edition. Oxford: Architectural Press.

NIEDERMAIER, P. (2016). Geneza orașelor medievale în Transilvania [Genesis of Middle Ages Towns in Transylvania].Bucharest: Editura Academiei Române.

PANTELIMON, C. (1977). Orașul Rupea. Studiu geografic complex. Lucrarea metodico-științifică pentru obținerea gradului didactic I [Rupea Town. Complex Geographical Study. Methodical-Scientific Thesis for Obtaining the $1^{\text {st }}$ Didactic Degree]. Cluj-Napoca: Babeș-Bolyai University (manuscript).

PETRESCU, C. (2012). Ultima noapte de dragoste, întâia noapte de război [The Last Night of Love, The First Night of War]. Bucharest: AGORA.

POLEDNA, R. (2001). SINT UT SUNT, AUT NON SINT? Transformări sociale la sașii ardeleni după 1945 [Social Transformations of the Transylvanian Saxons after 1945]. Cluj-Napoca: Presa Universitară Clujeană.

RATNER, C. (2008). Subjectivism. In: GIVEN, L. M. (ed.), The SAGE Encyclopedia of Qualitative Research Methods, volume 1 (pp. 839-843). London: SAGE.

THE EDITORS OF ENCYCLOPAEDIA BRITANNICA (2014). Iconography. In Encyclopædia Britannica. Retrieved 28 March 2018, from https://www.britannica.com/art/iconography.

WAGNER, E. (2000). Istoria sașilor ardeleni [History of the Transylvanian Saxons]. Bucharest: Editura Meronia. 